\title{
Malignant histiocytosis complicating rheumatoid arthritis: report of four cases
}

\author{
AS JACK, BF BOYCE, FD LEE \\ From the Department of Pathology, University of Glasgow, Glasgow Royal Infirmary, Glasgow
}

SUMMARY Four patients with rheumatoid arthritis developed a similar type of lymphoreticular tumour. The morphology and immunocytochemical findings suggested that this was a form of malignant histiocytosis: there may be an important correlation between this tumour and rheumatoid arthritis.

An association between lymphoreticular neoplasms and diseases affecting the immune system has often been described. B cell lymphomas are found in association with Hashimoto's thyroiditis, ${ }^{1}$ Sjogren's syndrome, ${ }^{2}$ immunosuppression, ${ }^{3}$ and the acquired immune deficiency syndrome (AIDS). ${ }^{4}$ The occurrence of malignant histiocytosis of the intestine in patients with coeliac disease is now well recognised. ${ }^{56}$

In contrast, lymphoreticular tumours have not been reported in rheumatoid arthritis or other related connective tissue disorders in which there is often evidence of lymphoid hyperplasia, autoantibody formation, and immune impairment. We describe four cases in which a distinctive form of lymphoreticular neoplasm occurred in patients with rheumatoid arthritis.

\section{Case reports}

\section{CLINICAL DETAILS}

Case 1 This patient, a 63 year old man, had been receiving treatment with non-steroidal antiinflammatory drugs and gold for seropositive rheumatoid arthritis for about two years before death. Gold treatment had induced a good symptomatic response. He was admitted to hospital shortly before his death with a history of fever and general malaise of recent onset. Chest radiography, computed tomography, and abdominal ultrasonography suggested the presence of disseminated tumour. A laparotomy was performed, which confirmed the presence of multiple tumour nodules in the liver. The spleen had been removed because of accidental surgical trauma.

Case 2 This patient, a 54 year old woman, was diagnosed as having seropositive rheumatoid arthritis six

Accepted for publication 16 September 1985 months before death. She had a symmetrical erosive arthropathy with an erythrocyte sedimentation rate measured at $130 \mathrm{~mm} /$ hour. This had been treated with non-steroidal anti-inflammatory drugs. She was admitted to hospital with rapidly progressive renal failure and died shortly after. A diffuse infiltrate had been noted on the chest $x$-ray

Case 3 This patient, a 56 year old woman, had nodular seropositive rheumatoid arthritis that had resulted in a flexion deformity of both knees. This had been present for more than five years. She had been treated with non-steroidal anti-inflammatory drugs. She was admitted to hospital with severe joint pain, jaundice, and vomiting. On examination she was shocked and hypoxic. She died a few hours later.

Case 4 This patient, a 77 year old woman, was known to have had seropositive rheumatoid arthritis for more than five years, resulting in a moderate degree of joint deformity. She had received treatment with gold and penicillamine. She was admitted to hospital complaining of upper abdominal pain which had started during the previous few days. Cholecystitis was diagnosed and a laparotomy was performed. The gall bladder was thickened and adherent, and the liver had a finely mottled appearance. Cholecystectomy and liver biopsy were performed. She was alive three months later.

Postmortem examinations were performed on cases $1-3$. The gall bladder and liver were examined in case 4.

IMMUNOCYTOCHEMICAL STUDIES

All cases were studied using standard indirect immunoperoxidase methods with the following antibodies: antileucocyte common antigen (Dako Ltd), antialpha-l-antitrypsin (Dako Ltd), anti-alpha-l-antichymotrypsin (Dako Ltd), antimuramidase (Dako Ltd), anti-leu-Ml (Becton-Dickinson), anti-S100 

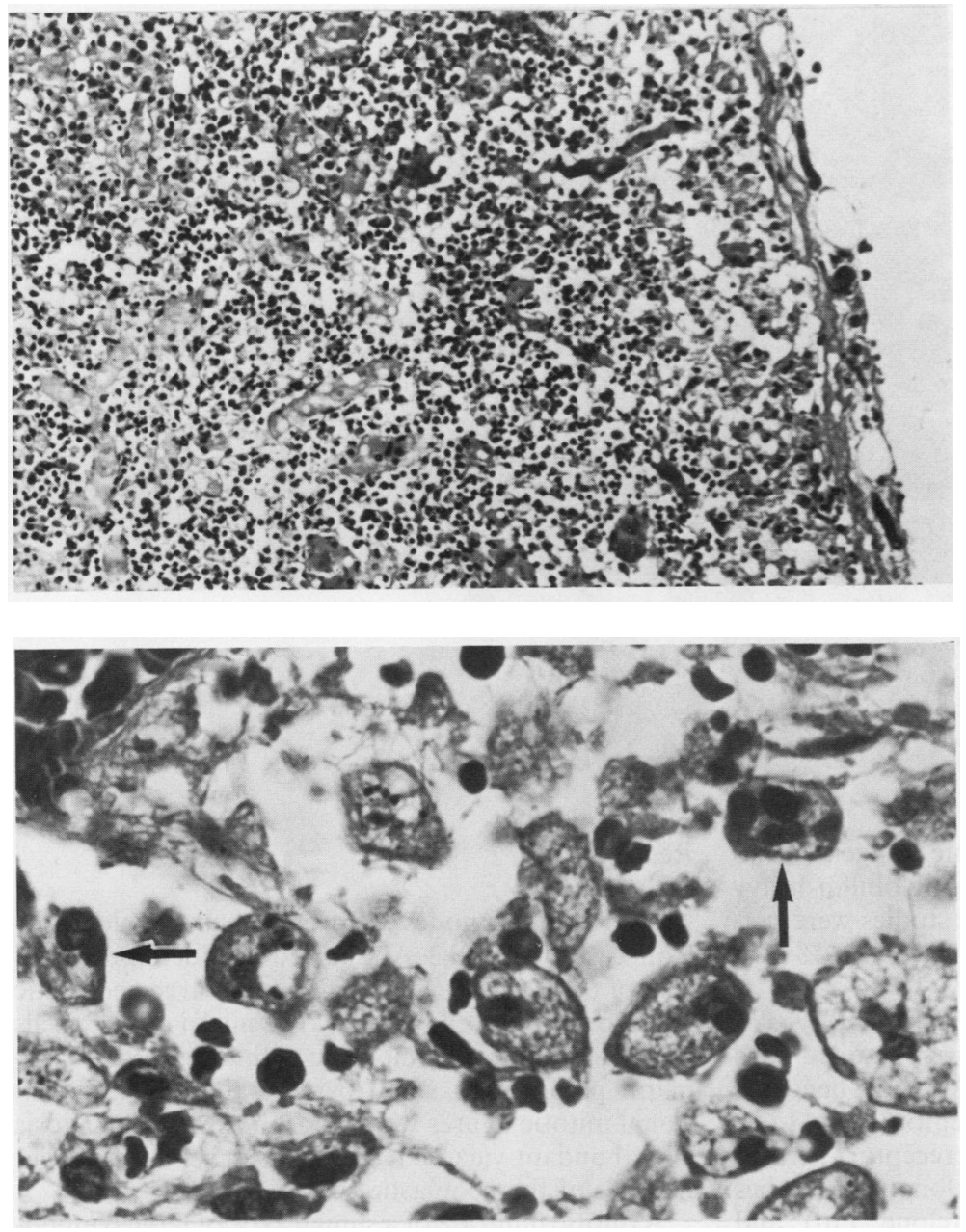

Fig. 1 Case 3 (lymph node). Lymph node sinuses, including marginal sinus, are distended by malignant histiocytes.

(Haematoxylin and eosin.) $\times 159$.

Fig. 2 Case 2 (lymph node). Malignant cells in marginal sinus of lymph node. Cells have atypical nuclei with vacuolated cytoplasm and evidence of erythrophagocytosis (arrows). (Haematoxylin and eosin.) $\times 786$.

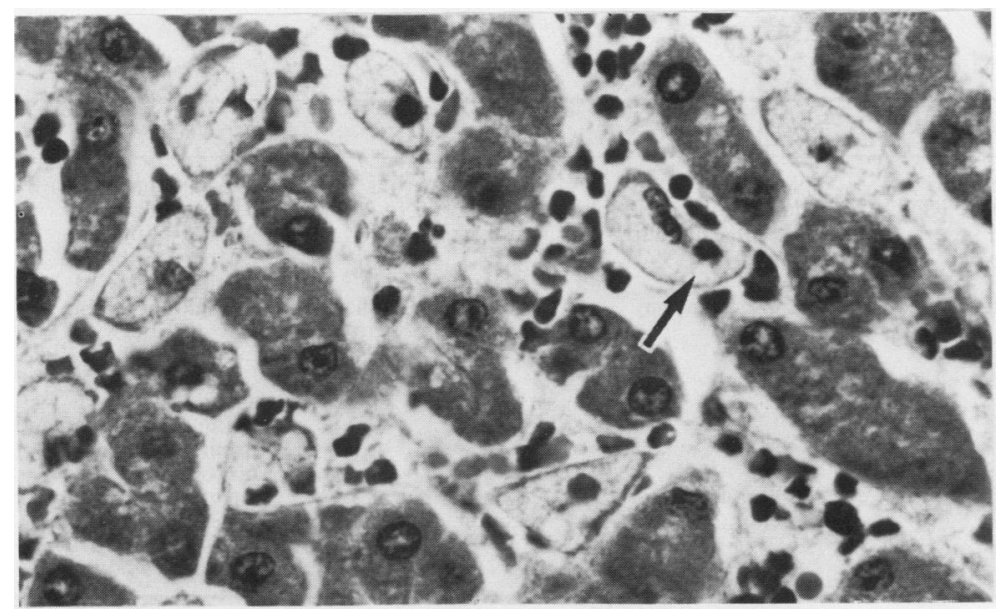

Fig. 3 Case 3 (liver). Numerous malignant histiocytes are seen infiltrating hepatic sinusoids. These are similar to those seen in case 2. Erythrophagocytosis is also seen. (arrow) (Haematoxylin and eosin.) $\times 627$. 


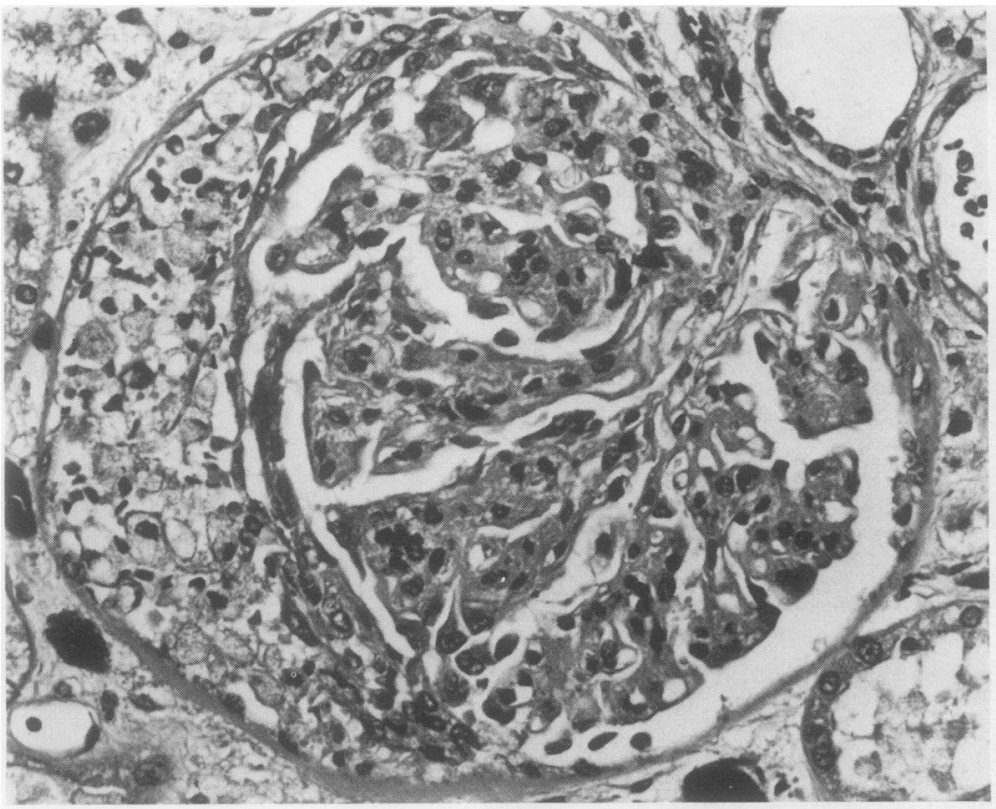

Fig. 4 Case 2 (kidney). Renal glomerulus with crescent formed mainly of malignant histiocytes. (Haematoxylin and eosin.) $\times 314$.

(Dako Ltd), antiepithelial membrane antigen (Dako Ltd), and antibodies against immunoglobulin heavy and light chains (Dako Ltd). These studies were performed on paraffin embedded tissue fixed in $10 \%$ neutral phosphate buffered formalin.

Unfixed tissue was available in case 4. Cryostat sections of liver and gall bladder were stained with antibodies to immunoglobulin (Dako Ltd), dendritic reticulum cells (Dako Ltd), C3B receptor (Dako Ltd), HLADR (Dako Ltd), interleukin 2 receptor (Serotec Ltd), and the anti-T-cell monoclonal antibodies OKT4A, OKT8, OKT11 (Orthorclone Ltd) and Dako T2 (Dako Ltd).

\section{Results}

Multiple lymph nodes were examined histologically from cases 1,2, and 3 . All showed considerable expansion of the sinuses by a population of large neoplastic lymphoreticular cells (Fig. 1). The nuclei of these cells were moderately pleomorphic with a dispersed chromatin pattern and small peripheral nucleoli. Occasional mitotic figures were seen. Erythrophagocytosis and abundant vacuolated cytoplasm were prominent features of the neoplastic cells (Fig. 2).

A diffuse infiltrate of a similar type of large lymphoreticular cell was seen in the splenic and hepatic

Clinical and necropsy findings in cases 1-3

\begin{tabular}{|c|c|c|c|c|c|}
\hline Case no & Mode of death & Lymphadenopathy & Spleen & Liver & Other findings \\
\hline 1 & $\begin{array}{l}\text { Shock, respiratory } \\
\text { failure, acute renal } \\
\text { failure }\end{array}$ & $\begin{array}{l}\text { Several necrotic } \\
\text { para-aortic lymph } \\
\text { nodes }\end{array}$ & $\begin{array}{l}\text { Spleen removed at } \\
\text { laparotomy; multiple } \\
\text { necrotic tumour } \\
\text { present }\end{array}$ & $\begin{array}{l}1700 \mathrm{~g} \text {; numerous } \\
\text { nodules up to } 20 \mathrm{~mm} \\
\text { in diameter }\end{array}$ & $\begin{array}{l}\text { Increasing anaemia with } \\
\text { haemoglobin of } \\
9.9 \mathrm{gd}^{\mathrm{P}-1} \text { and } \\
\text { leucoerythroblastic } \\
\text { reaction }\end{array}$ \\
\hline 2 & $\begin{array}{l}\text { Progressive renal and } \\
\text { respiratory failure }\end{array}$ & $\begin{array}{l}\text { Few enlarged hilar } \\
\text { nodes }\end{array}$ & $\begin{array}{l}200 \mathrm{~g} \text {; normal on } \\
\text { section }\end{array}$ & $\begin{array}{l}2.5 \mathrm{~kg} \text {; macroscopically } \\
\text { normal on section }\end{array}$ & $\begin{array}{l}\text { Haemoglobin falling } \\
\text { before death with } \\
\text { moderately increased } \\
\text { femoral red marrow at } \\
\text { autopsy } \\
\text { Lungs congested and } \\
\text { haemorrhagic at } \\
\text { necropsy }\end{array}$ \\
\hline 3 & $\begin{array}{l}\text { Shock and respiratory } \\
\text { failure; septicaemia } \\
\text { suspected but no } \\
\text { organism cultured }\end{array}$ & Not noted & $\begin{array}{l}470 \mathrm{~g} \text {; normal on } \\
\text { section }\end{array}$ & $\begin{array}{l}1.9 \mathrm{~kg} \text {; normal on } \\
\text { section }\end{array}$ & $\begin{array}{c}\text { Basal bronchopneumonia. } \\
\text { Severe increase in } \\
\text { femoral red marrow; } \\
\text { no recent blood count }\end{array}$ \\
\hline
\end{tabular}




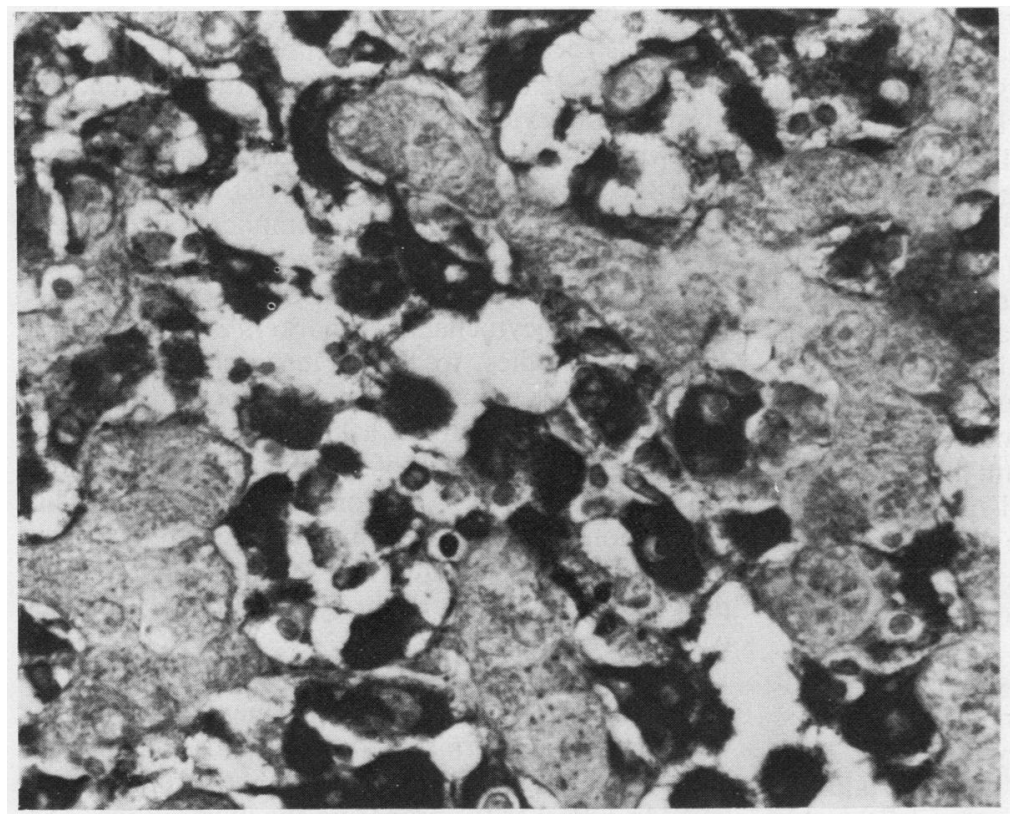

Fig. 5 Case 4 (liver). Intense cytoplasmic staining of infiltrating malignant histiocytes. Surrounding hepatocytes are unstained. Indirect immunoperoxidase using alpha-lanti-chymotrypsin. $\times 502$.

sinuses (Fig. 3) and in bone marrow from cases 1-3. In case 1 there were tumour nodules in the liver and lung, some of which had undergone central necrosis. The spleen, which had been removed previously, contained multiple necrotic nodules similar to those in the liver and lung. In case 2 renal glomerular crescents were present consisting partly of cells similar to those in lymph node sinuses (Fig. 4). This feature was also present, although to a lesser extent, in case 3 . In cases 2 and 3 an infiltrate of neoplastic lymphoreticular cells was also seen in the pulmonary alveoli.

In case 4 cells similar to those described above were seen infiltrating hepatic sinusoids. Tumour nodules were present in the gall bladder wall and aggregates of these cells were seen within adjacent lymphatic vessels. Some of the cells in this case had bilobed nuclei and bore a resemblance to Reed-Sternberg cells. This infiltrate was accompanied by large numbers of small lymphoid cells, granulocytes (including eosinophils), and occasional plasma cells. This was most noticeable in the portal tracts of the liver and in the tumour deposits found in the gall bladder wall.

The Table gives additional clinical and pathological details.

In all four cases the infiltrating neoplastic cell population stained positively with the antibody to alphal-antichymotrypsin. This produced a granular cytoplasmic pattern of staining (Fig. 5). Some cells showed polytypic weak cytoplasmic immunoglobulin staining. No reaction was seen with any of the other antibodies used. In the case where cryostat sections were available the neoplastic cells were associated with an infiltrate of small reactive lymphocytes. This was identified as predominantly $\mathrm{T}$ cell in composition. Both helper and suppressor or cytotoxic $T$ cells were present, with a predominance of helper cells.

\section{Discussion}

Four patients with rheumatoid arthritis were found to have diffuse lymphoreticular neoplasms of a distinctive type, characterised by diffuse infiltration of the sinusoids of the liver, spleen, and bone marrow by a population of large lymphoreticular cells that showed nuclear atypia, vacuolated cytoplasm, and erythrophagocytosis. This is similar to the condition known as histiocytic medullary reticulosis ${ }^{7}$ or malignant histiocytosis. ${ }^{8}$ Another feature indicative of histiocytic differentiation was the positive staining of the tumour cells with anti-alpha-l-antichymotrypsin. None of these patients was known to have pancytopenia, which has been described as a common feature in histiocytic medullary reticulosis. Nevertheless, progressive anaemia was seen in cases 1 and 2 . Cases 1 and 4 differed from the others in that the tumours were present in addition to a diffuse infiltrate. It is conventional to regard the presence of solid tumour masses as indicative of true histiocytic lymphoma rather than malignant histiocytosis, but overlap between these conditions is known to occur. ${ }^{9}$ In addition, malignant histiocytosis of the intestine may present as local tumour masses in the small intestine 
but may infiltrate diffusely in other organs. ${ }^{56}$

Identifying histiocytic tumours has been a controversial matter for many years. This has been partly due to the use of the term histiocytic by the Rappaport classification for tumours of $\mathrm{B}$ or $\mathrm{T}$ cell. ${ }^{10}$ The incidence of histiocytic tumours has been variously quoted as less than $1 \%{ }^{11}$ or $10-15 \% .{ }^{1213}$ The cause of this discrepancy is related to the importance attached to alpha-l-antitrypsin staining as a reliable marker of histiocyte differentiation and the use of the Hodgkin's disease related monoclonal antibodies, $\mathrm{Ki}-\mathrm{l}$ and Leu Ml. ${ }^{11}$ The difficulties have been exacerbated by a recent report on monotypic surface immunoglobulin staining in malignant histiocytosis of the intestine using the immuno-gold-silver method. ${ }^{14}$ In the cases described above the term malignant histiocytosis is a useful description, but clearly some doubt must remain as to the true histogenesis of these lesions.

Two other differential diagnoses should be considered in these cases. A benign virus induced histiocytic proliferation with erythrophagocytosis has been described. This is associated with a high mortality. ${ }^{15}$ The cases we described were differentiated from this condition by the presence of conspicuous nuclear atypia and by tumour formation in cases 1 and 4 . The second possible differential diagnosis is the haemophagocytic $\mathbf{T}$ cell lymphoma or leukaemia, described by Kadin. ${ }^{16}$ None of the cases described was leukaemic, but a $\mathrm{T}$ cell origin of the lesion cannot be excluded in the absence of appropriate markers in three cases. It has been proposed that malignant histiocytosis and haemophagocytic $\mathrm{T}$ cell lymphoma are closely related, with several patients being described who have features of both conditions. ${ }^{17}$

The cases were collected over four years during which time only one other case of malignant histiocytosis was diagnosed in this department, excluding coeliac related malignant histiocytosis of the intestine. This points to a true rather than a fortuitous correlation with rheumatoid arthritis. The man and three women described reflect the sex preference of rheumatoid arthritis; the age range, however (54-77 years) is older than the usual age of onset of rheumatoid arthritis, the third to fourth decade. Two of the patients had relatively short histories of joint disease, but the other patients had been receiving treatment for over five years. There seems to be no consistency between patients as regards treatment other than non-steroidal anti-inflammatory drugs. All four patients presented with an acute illness, followed in cases 1-3 with rapid deterioration and death. One patient (case 4) is alive three months after presentation and is being treated with chemotherapy.

An interesting feature of case 2 was the presentation with renal failure and the subsequent finding of glo- merular crescents partly composed of neoplastic cells. This has been previously reported in malignant histiocytosis ${ }^{18}$ and is consistent with the presence of normal histiocytes in Bowman's capsule. ${ }^{19}$

It would be interesting to know if similar cases have been recognised elsewhere, so that the incidence of malignant histiocytosis as a complication of rheumatoid arthritis could be assessed. If tissue were to become available from other cases it may be possible, using immunocytochemical markers and gene rearrangement studies, to further characterise the cells present in these tumours. Such studies could elucidate further what seems to be a link between the immunological abnormalities of rheumatoid arthritis and the development of lymphoreticular tumours. This association is also interesting in view of the rheumatoid induced proliferation of the mononuclear phagocyte component of the synovial lining, ${ }^{20}$ which occurs in affected joints.

We thank Dr R Madhok, department of medicine, Glasgow Royal Infirmary, for helpful discussions. We are grateful to Mrs I Main for typing the manuscript and $\mathrm{Mr} \mathrm{T}$ Parker for preparing the illustrations. ASJ is supported by the Wellcome Trust.

\section{References}

${ }^{1}$ Anscombe AM, Wright DH. Primary malignant lymphomas of the thyroid - a tumour of mucosa associated lymphoid tissue: review of seventy-six cases. Histopathology 1985;9:81-97.

2 Zulman J, Jaffe R, Talal N. Evidence that the malignant lymphoma of Sjogren's syndrome is a monoclonal B-cell neoplasm. New Engl J Med 1978;299:1215-20.

${ }^{3}$ Cleary ML, Sklar J. Lymphoproliferative disorders in cardiac transplantation recipients are multiclonal lymphomas. Lance 1984;ii:489-93.

${ }^{4}$ Reichert CM, O'Leary TJ, Levens DL, Simrell CR, Macher AM Autopsy pathology in the acquired immune deficiency syndrome. Am J Pathol 1983;112:357-82.

s Isaacson P, Wright DH. Intestinal lymphoma associated with malabsorption. Lancet 1978;i:67-70.

${ }^{6}$ Isaacson P, Wright DH. Malignant histocytosis of the intestine. Its relationship to malabsorption and ulcerative jejunitis. Hum Pathol 1978;9:661-77.

${ }^{7}$ Scott RB, Robb-Smith AHT. Histiocytic medullary reticulosis. Lancet 1939; ii:194-8.

${ }^{8}$ Rappaport H. Tumours of the hematopoietic system. Atlas of tumour pathology. Washington DC: Armed Forces Institute of Pathology, 1966:36-43.

${ }^{9}$ Warnke RA, Kim H, Dorfman RF. Malignant histiocytosis (histiocytic medullary reticulosis). I. Clinico-pathologic study of 29 cases. Cancer 1975;35:215-30.

${ }^{10}$ Nathwani BN. A critical analysis of classifications of nonHodgkin's lymphoma. Cancer 1979;44:347-8.

${ }^{11}$ Stein H, Lennert K, Feller AC, Masson DY. Immunohistological analysis of human lymphoma: correlation of histological and immunological categories. Adv Cancer Res 1985;42:67-143.

12 Van der Valk P, Meijer CJLM, Willemze R, Van Oosterom AT, Spaander PJ, TeVelde J. Histiocytic sarcoma (true histiocytic lymphoma) a clinicopathological study of 20 cases. Histopathology 1984;8:105-23. 
${ }^{13}$ Van der Valk P, Herman J, Brand R, Cornelisse CJ, Spaander PJ, Meijer CJLM. Morphometric characterisation of diffuse large cell (histiocytic) lymphomas. Am J Pathol 1982;107:327-55.

${ }^{14}$ Morgan DR, Holgate CS, Dixon MF, Bird CC. Classification of small bowel lymphoma by immunogold silver technique: relationship with coeliac disease. $J$ Pathol 1985;146:241A.

${ }^{15}$ Risdall RJ, McKenna RW, Nesbit ME, et al. Virus associated haemophagocytic syndrome: a benign histiocytic proliferation distinct from malignant histiocytosis. Cancer 1979;44:993-1002.

${ }^{16} \mathrm{Kadin}$ ME, Kamoun M, Lamberg J. Erythrophagocytic T-gamma lymphoma. A clinicopathologic entity resembling malignant histiocytosis. N Engl J Med 1981;304:648-9.

${ }^{17}$ Kadin ME. T-gamma cells: a missing link between malignant histiocytosis and T-cell leukaemia-lymphoma? Hum Pathol 1981;12:771-2.
${ }^{18}$ Aozasa K, Tsujimoto M, Inoue A. Malignant histiocytosis. Report of twenty five cases with pulmonary, renal and/or gastrointestinal involvement. Histopathology 1985;9:39-49.

${ }^{19}$ Thomson WM, Holdworth SR, Glasgow EF, Atkin RC. The macrophage in the development of experimental crescentic glomerulonephritis. Studies using tissue culture and electron microscopy. Am J Pathol 1979;94:223-40.

${ }^{20}$ Ghadially FN. The articular territory of the reticuloendothelial system. Ultrastruct Pathol 1980;1:249-58.

Requests for reprints to: Dr AS Jack, Department of Pathology, Royal Infirmary, Glasgow G4 OSF, Scotland. 